\title{
Heart Failure as a Comorbidity of Diabetes: Role of Dipeptidyl Peptidase 4
}

\author{
Yasuko K. Bando and Toyoaki Murohara
}

Department of Cardiology, Nagoya University Graduate School of Medicine, Nagoya, Japan

Heart failure is a primary cause of death worldwide, and it is notable that heart failure patients exhibit a high incidence of diabetes. On the other hand, comorbid diabetes significantly worsens the prognosis of heart failure, even independently of complicated coronary artery disease.

To date, heart failure caused by diabetes has been designated as "diabetic cardiomyopathy (DMC)," and a recent cohort study of the large-scale (1.9 million people) research platform of linked electronic medical records in UK (CALIBER registry) demonstrated that heart failure and peripheral arterial disease are the most common initial manifestations of cardiovascular disease in type 2 diabetes. The underlying pathophysiology has been characterized as microvasculopathy, myocardial hypertrophy, and cardiac fibrosis; however, these evidences are mostly obtained under a preclinical setting, and its clinical application on DMC in terms of its diagnosis and therapeutic intervention yet has reached practical. Our group has focused on and clarified the molecular mechanisms underlying DMC both in preclinical and clinical settings and has found the primary role of "dipeptidyl peptidase-4 (DPP4)" in the pathogenesis of diabetic microvasculopathy in the heart. Moreover, there are evidences implicating the potent role of circulating DPP4 activity in the diagnosis of diastolic heart failure. The present review aimed to review the current comprehension regarding diabetes and heart failure and discuss the therapeutic and diagnostic roles of DPP4.

J Atheroscler Thromb, 2016; 23: 147-154.

Key words: Diabetes, Heart failure, Dipeptidyl peptidase 4, Diabetic cardiomyopathy

\section{DMC: Past and Present Concepts}

The link between diabetes and HF was first documented in $1881^{1,2)}$, and the term DMC was coined in $1972^{3)}$. Case reports demonstrated the pathophysiological characteristics of the clinical entity such as "microvascular remodeling of coronary arteriole" and "enhanced cardiac fibrosis"3, 4). These early reports seemed to focus on the end-staged DMC of HF-REF with comorbid diabetic nephropathy and retinopathy.

In 2013, the ACCF/AHA and the ESC/EASD at last denoted the definition of $\mathrm{DMC}^{5,6)}$ (it remains undetermined in Japanese guidelines). These guidelines define DMC as follows: "DMC is a clinical con-

Address for correspondence: Yasuko K. Bando, Department of Cardiology, Nagoya University Graduate School of Medicine, 65 Tsurumai-cho, Showa-ku, Nagoya, Aichi, 466-8550 JAPAN Email: ybando@med.nagoya-u.ac.jp

Received: September 25, 2015

Accepted for publication: October 23, 2015 dition diagnosed when ventricular dysfunction occurs in the absence of coronary atherosclerosis and hypertension" 5). However, this statement gives no concrete definition on the ventricular dysfunction and/or diabetic myocardial remodeling. In DMC, one of the most popular clinical conditions observed in DMC is diastolic dysfunction $(\mathrm{HF}-\mathrm{PEF})^{7,8)}$. Therefore, the terminology of DMC might be revised for reflecting each disease condition more accurately in terms of these clinical and pathological features.

Characteristics of the Diabetic Burdens on the Heart: Microvasculopathy, Myocardial Hypertrophy, Fibrosis, and Prothrombogenic Phenotype

Diabetes causes a wide variety of myocardial damages such as microvasculopathy, myocardial hypertrophy, fibrosis, and prothrombogenic phenotype via glucotoxicity and lipotoxicity ${ }^{7,9,10)}$. The spa- 
tio-temporal relationship among these pathological changes in myocardial remodeling remains unclear. However, clinical evidence provided by UKPDS35 demonstrated that the incidence of macrovasculopathy was higher than microvasculopathy during $\mathrm{HbA1C}$ remains relatively low level ${ }^{5,11)}$.

\section{Microvasculopathy}

In diabetes, both gluco- and lipo-toxicities are considered as a primary cause for increasing oxidative stress and chronic inflammation, leading to microvasculopathy ${ }^{5,12,13)}$. Interesting reports demonstrated that diabetic retinopathy predicts the incidence of $\mathrm{HF}^{14)}$ and reflects diastolic cardiac dysfunction in diabetic patients ${ }^{15,16)}$. Because the retina is the only window where one can observe microvascular damage in an extracorporeal fashion, retinopathy may thus represent vascular damage and injury not only in the eyes but also in other vital organs such as the heart in diabetic patients. Recently, Kawata et al. demonstrated that coronary flow reserve (CFR), which reflects coronary microvascular function, is associated with left ventricular diastolic dysfunction in patients with type 2 diabetes ${ }^{17)}$. Furthermore, an interesting evidence demonstrated that those patients with retinopathy are prone to display diastolic left ventricular dysfunction ${ }^{15)}$.

One of the primary mediators promoting microvasculopathy is the AGE/RAGE axis ${ }^{18)}$. Notably, there is a novel link between the AGE/RAGE axis and DPP4 ${ }^{19)}$, a known inflammatory mediator ${ }^{20,21)}$ that is involved in the pathophysiology of cardiovascular diseases $^{22,23)}$. Diabetes enhances DPP4 activity ${ }^{24,25)}$ that links to the AGE/RAGE axis. Consistently, recent studies suggest that DPP4 inhibitors ameliorate macro- ${ }^{26)}$ and micro-vascular endothelial damage ${ }^{24)}$ in diabetes via its anti-inflammatory effects ${ }^{26,27)}$.

\section{Myocardial Hypertrophy}

Myocardial hypertrophy is another feature of DMC that causes diastolic dysfunction as a typical cardiac dysfunction observed in diabetes. One of the primary factors causing its pathogenesis is hyperinsulinemia as well as impaired insulin signaling of the myocardium ${ }^{28)}$. Insulin is mitogenic and prosurvival under healthy circumstance, and it promotes hypertrophy in cardiomyocytes ${ }^{29}$. Indeed, type 1 diabetic rodents generated by streptozotocin-induced insulin deficiency exhibits myocardial atrophy ${ }^{30)}$. The myocardium possesses an insulin receptor that determines its innate insulin signaling pathway connecting to metabolic $^{31)}$ and mitochondrial remodeling ${ }^{31-33)}$. It gains consensus that an abnormal excess of insulin signaling exerts vicious effects on the cardiovascular sys- tem, primarily because of oxidative stress through mitochondrial dysfunction even independently of comorbid diabetes, which was elegantly demonstrated by the use of a pressure-overloaded HF model ${ }^{34)}$.

Another considerable pathology that could result in diabetic myocardial hypertrophy is cardiac steato$\operatorname{sis}^{35-37)}$. Diabetes promotes dyslipidemia and myocardial metabolic remodeling through an increase in free fatty acids ${ }^{31)}$ that causes an abnormal accumulation of large-sized lipids (e.g., triglyceride) into the cardiac cells in addition to the deposition of excess epicardial fat. The precise mechanisms underlying the myocardial accumulation of the lipids remain unknown; however, several clinical reports demonstrated that cardiac steatosis is observed even at the prediabetic state and causes diastolic dysfunction, and magnetic resonance spectroscopy is a good tool to detect abnormal TG accumulation in the heart ${ }^{38,39)}$.

\section{Increase in Cardiac Fibrosis}

Cardiac fibrosis is another feature of diabetes. The impact of diabetes on cardiac fibrosis is presumably similar to the mechanism that is observed in diabetic nephropathy ${ }^{40,41)}$. Four primary factors responsible for the cardiac fibrosis of DMC are as follows: First, the RAAS that activates TGF- $\beta 1$ pathway ${ }^{40)}$; second, the AGE/RAGE axis that suppresses collagen turnover via an abnormal crosslinking of collagen $^{42)}$; third, hyperinsulinemia that impairs the differentiation of fibroblast progenitor cells ${ }^{43)}$; and fourth, dysregulation of extracellular matrix degradation ${ }^{44)}$.

Recently, we and others reported that DPP4 inhibitors attenuate myocardial fibrosis independently of diabetes. Interestingly, the DPP 4 inhibitors have been reported to suppress renal and hepatic fibrosis ${ }^{45}$, 46). Consistently with these notion, the DPP family (DPP8/9) has characteristics of a collagenase as well as a fibroblast activating protein (FAP) ${ }^{47)}$ and, likewise DPP8/9, DPP4 is reported to have an capacity for a collagenase.

\section{Prothrombogenic Phenotype}

Abnormalities in platelet function are another cardiovascular risk observed not only in diabetes ${ }^{48)}$ but also in the prediabetic state ${ }^{49)}$. The primary cause of enhanced platelet aggregation observed in diabetes is hyperglycemia and hyperinsulinemia, leading to platelet activation and oxidative stress ${ }^{48-50}$. In addition to macrovascular thrombosis, microvascular thrombosis could occur in diabetes ${ }^{51)}$. Therefore, the prothrombotic phenotype may link to an impaired coronary microcirculation and the resultant cardiac dysfunction $^{7,52,53)}$. Collectively, potential benefits promoted 

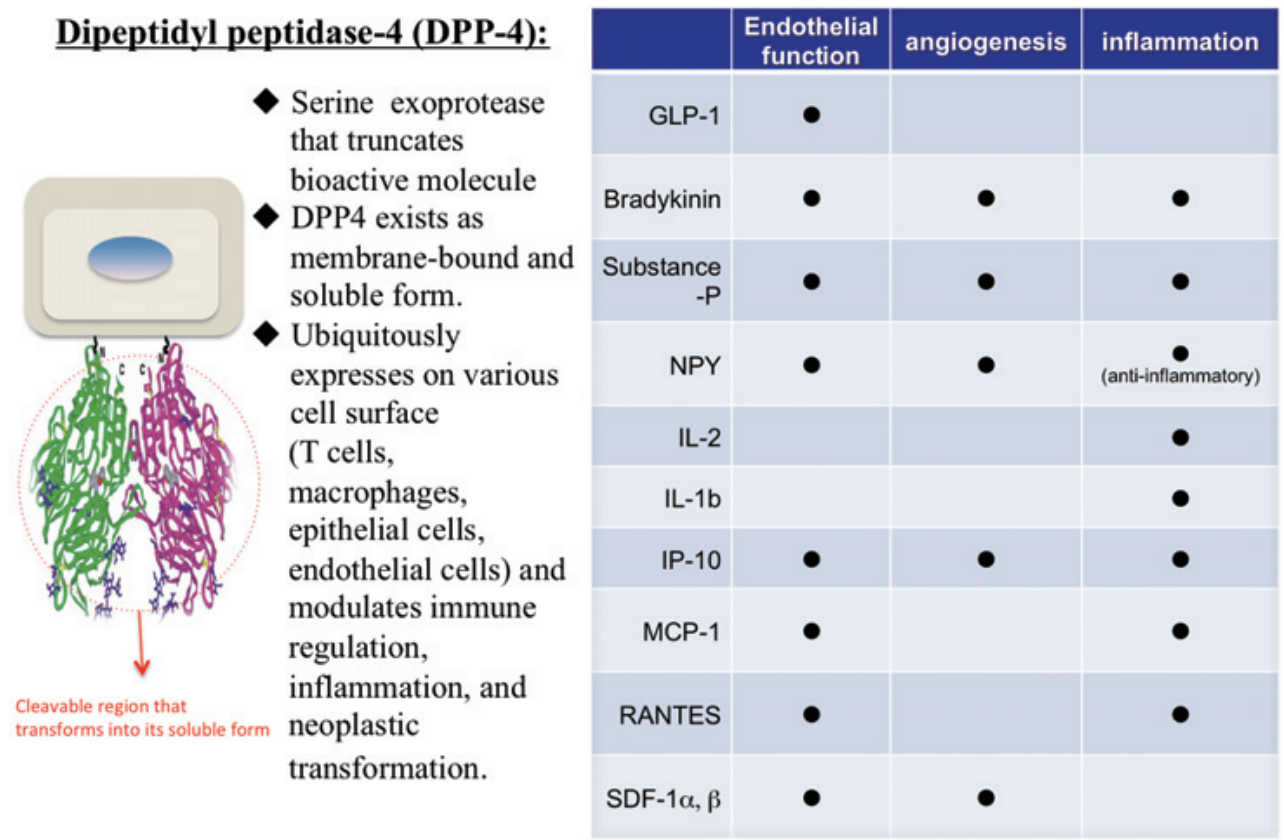

Fig. 1. DPP4 is a serine protease that ubiquitously expressed in the whole body. Table summarized various substrates of DPP4 that modulates cardiovasuclar pathophysiology.

by the administration of anti-platelet drugs are strongly expected for diabetic patients ${ }^{54,55)}$. DPP4 per se possesses anti-thrombotic properties and may behave as an immobilized anti-coagulant on endothelial cells. Under nondiabetic conditions, ischemia/ hypoxia induces the loss of coronary microvascular endothelial DPP4 expression and increased tissue factor expression in $\mathrm{AMI}^{56)}$.

\section{Hemodynamic Characteristics Induced by Diabetes}

Hemodynamic characteristics of DMC likely reflects the above four pathological changes. The hemodynamic changes observed in the diabetic heart occurs both in systolic and diastolic functions. As ample reviews have noted, all pathological changes of the diabetic heart cause a diastolic dysfunction ${ }^{5,57)}$. Diabetes-induced systolic dysfunction has been clinically less popular, except for genetic cardiomyopathy that is caused by mitochondria disorders ${ }^{58)}$. However, several clinical studies have clearly shown the link between diabetes and systolic dysfunction under an asymptomatic state ${ }^{59,60)}$. In a preclinical setting, hyperglycemia promotes systolic dysfunction in type 1 diabetic rodents ${ }^{30)}$. The cause of systolic dysfunction was explained because of cardiac negative remodeling induced by insulin deficiency and hyperglycemia- induced impaired $\mathrm{Ca}^{2+}$ homeostasis ${ }^{61)}$.

\section{DPP4 Inhibition in Heart Failure: Friend or Foe?}

DPP4 (DPP4/DPPIV/CD26) is a $110-\mathrm{kDa}$ type II integral membrane glycoprotein that cleaves $\mathrm{N}$-terminal dipeptides from peptides with preferably proline or alanine at the penultimate ${ }^{62}$. Interestingly, these substrates are bioactive peptides that regulate the cardiovascular system ${ }^{63,64)}$ (Fig. 1), and its activity level alters in response to the comorbid diseases. For instance, diabetes enhances membrane-bound type DPP4 activity ${ }^{24,25)}$, which is suppressed by non-diabetic cardiac stress (Fig. 2) ${ }^{23,24)}$. Therefore, DPP4 inhibitors and its major substrate incretin peptides are expected to play beneficial roles in various cardiovascular diseases. Indeed, preclinical evidences and phasetrials consistently proved their protective roles; therefore, the large-scale randomized studies were expected to provide any favorable results in terms of cardiovascular protection in diabetic patients, although these were intension-to-treat data obtained from these trials, which were designed as a safety test for antidiabetic remedies according to the recommendation stated by USFDA $^{65,66)}$. The year 2013 was a milestone year for the clinical aspects of the "diabetes-related heart failure" based on two important events: one was a major 


\section{Chromnic Inflammation (e.g. Diabetes, Cancer, Autoimmune disease)}

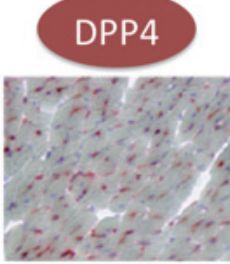

\section{DPP4}
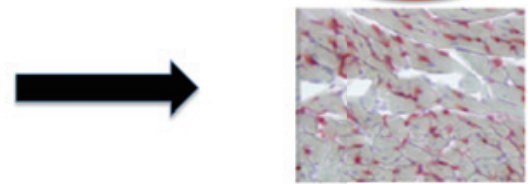

Acute Inflammation/Hypoxia (e.g. Myocardial infarction, TAC)
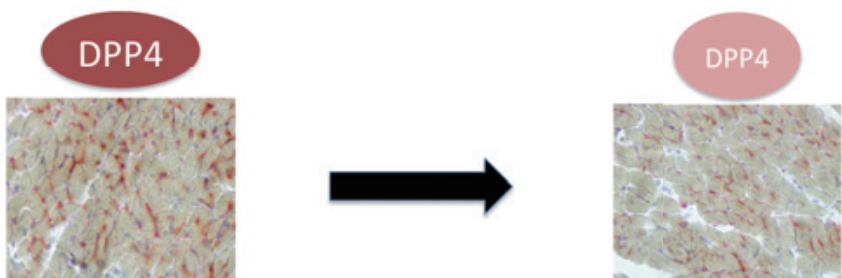

Fig. 2. Alternative changes of cardiac DPP4 activity. Cardiac DPP4 is expressed in capillary endothelial cells and its activity dversely changes. DPP4; Dipeptidyl peptidase, TAC; pressure-overload-induced heart failure.

revision of the clinical guidelines for heart failure with comorbid diabetes ${ }^{5}$, and the other was the unexpected increase in the incidence of HF observed in RCT for saxagliptin and placebo ${ }^{67)}$. In response to FDA's recommendation for the assessment of the cardiovascular safety of anti-diabetes remedies, the two trials enrolled T2DM patients with a high cardiovascular risk such as a history or risk of cardiovascular events in SAVORTIMI53 ${ }^{67)}$ and a recent acute coronary syndrome event in EXAMINE ${ }^{68)}$. Both trials assessed non-inferiority for the risk of major adverse cardiovascular events. Indeed, these trials proved the safety of these "gliptins"; however, in saxagliptin arms, the unexpected increase in the incidence of heart failure was observed. The SAVOR-TIMI groups immediately published the subanalysis results regarding the increase in the incidence of heart failure and demonstrated the risk factors for heart failure as follows: past medical history of heart failure, CKD, aging, male gender, insulin use, and race (i.e., Caucasian). This paper also mentioned about its limitation that there was no increase in myocardial injury markers such as BNP and troponin I, and the underlying mechanisms remain uncertain ${ }^{69)}$. On the other hand, the subanalysis of the EXAMINE trial clearly demonstrated that there was no influence of the past history of heart fail- ure on the incidence of heart failure, and they also consistently demonstrated that alogliptin had no effects on myocardial injury markers ${ }^{65}$. Furthermore, the TECOS trial, another RCT of DPP4 inhibitor sitagliptin, revealed that DPP4 inhibition did not increase the risk of any cardiovascular diseases, including heart failure ${ }^{70)}$ (Table 1 and 2). Taken together, the unexpected risk of heart failure observed in the SAVOR-TIMI53 trial was presumably independent from the drug-class effect of DPP4 inhibitors. A further prospective study for the evaluation of the risk of heart failure induced by anti-diabetic remedies are awaited under consideration for the incidence of hypoglycemia, clinical report bias for the diagnosis of heart failure, and assessment of cardiac function.

\section{Conclusion and Perspective}

The last question is how we diagnose DMC? To date, no surrogate markers have gained consensus as a diagnostic tool for DMC, i.e., this is one of the critical causes why DMC has been a clinically uncommon diagnosis. Further basic and clinical evidences are needed to establish the diagnostic and therapeutic guidelines for DMC. 
Table 1. Comparison of study characeteristics of the recent randamized large cohort trials for DPP4 inhibitors.

\begin{tabular}{|l|c|c|c|}
\hline & SAVOR-TIMI-53 & EXAMINE & TECOS \\
\hline Enrollment & 16,492 & 5,380 & 14,724 \\
\hline Gliptins & Saxagliptin & Alogliptin & Sitagliptin \\
\hline HbA1C(median\%) & $6.5-12 \%$ & $6.5-11 \%$ & $6.5-8 \%$ \\
\hline Age (Median, y/o) & 65 & 61 & 65 \\
\hline DM duration(year) & 10.3 & 7.3 & 9.4 \\
\hline Hypertension(\%) & 82 & 83 & 86 \\
\hline Dyslipidemia(\%) & 71 & N/A & 77 \\
\hline Smoker(\%) & N/A & 14 & 11 \\
\hline Hx of HF(\%) & 13 & 28 & 18 \\
\hline $\begin{array}{l}\text { Trial } \\
\text { period(median) }\end{array}$ & 2.1 years & 18 months & 3 years \\
\hline
\end{tabular}

Table 2. Summary of the clinical outcomes of the recent randamized large cohort trials for DPP4 inhibitors.

\begin{tabular}{|c|c|c|c|}
\hline Trial components & SAVOR-TIMI-53 & EXAMINE & TECOS \\
\hline $\begin{array}{l}\text { Clinical } \\
\text { outcomes }\end{array}$ & & & \\
\hline $\begin{array}{l}\text { CV death, } \\
\text { nonfatal MI/ } \\
\text { CAD }\end{array}$ & HR 1.00 (NS) & HR 1.00 (NS) & HR0.98 (NS) \\
\hline $\begin{array}{l}\text { Death from any } \\
\text { cause }\end{array}$ & HR 1.11 (NS) & HR 0.88 (NS) & HR 1.01 (NS) \\
\hline $\begin{array}{l}\text { Hospitalization } \\
\text { for } \mathrm{HF}\end{array}$ & HR 1.27* & HR 1.19 (NS) & HR1.00 (NS) \\
\hline
\end{tabular}

\section{Acknowledgements}

This work was supported by Japanese Society for the Promotion of Science Grant-in-Aid for Scientific Research (\#23591080 to YKB and \#20249045 to TM), Nagoya University Sentan Iryou Kenkyu Shien (to YKB and TM).

\section{Conflict of Interest}

Research grants from Daiichi-Sankyo, Astra Zeneca, Tanabe-Mitsubishi, (to YKB). Actelion, Astellas, Bayer, Boehringer Ingelheim, Chugai, Daiichi Sankyo, Dainippon Sumitomo, Eisai, Fuji Film RI, Kaken, Kowa, Kureha, Medtronic, Denso, Mochida, MSD, Novartis, Pfizer, Sanofi-Aventis, Schering-Plough, and Takeda (to TM). However, the research topics of these donation grants are not restricted. Lecturer's fee from MSD, AstraZeneca, and Tanabe-Mitsubishi (to YKB and TM) and lecturer's fees from Daiichi Sankyo, Novartis Pharma, Pfizer, and Takeda (to TM).

\section{References}

1) Leyden E: Asthma and diabetes mellitus. Zeutschr Klin Med, 1881; 3: 358-364

2) Asghar O, Al-Sunni A, Khavandi K, Khavandi A, Withers S, Greenstein A, Heagerty AM and Malik RA: Diabetic cardiomyopathy. Clin Sci (Lond), 2009; 116: 741-760

3) Rubler S, Dlugash J, Yuceoglu YZ, Kumral T, Branwood AW and Grishman A: New type of cardiomyopathy associated with diabetic glomerulosclerosis. The American journal of cardiology, 1972; 30: 595-602

4) Factor SM, Okun EM and Minase T: Capillary microaneurysms in the human diabetic heart. The New England journal of medicine, 1980; 302: 384-388

5) Ryden L, Grant PJ, Anker SD, Berne C, Cosentino F, 
Danchin N, Deaton C, Escaned J, Hammes HP, Huikuri H, Marre M, Marx N, Mellbin L, Ostergren J, Patrono C, Seferovic P, Uva MS, Taskinen MR, Tendera M, Tuomilehto J, Valensi P, Zamorano JL, Zamorano JL, Achenbach S, Baumgartner H, Bax JJ, Bueno H, Dean V, Deaton C, Erol C, Fagard R, Ferrari R, Hasdai D, Hoes AW, Kirchhof P, Knuuti J, Kolh P, Lancellotti P, Linhart A, Nihoyannopoulos P, Piepoli MF, Ponikowski P, Sirnes PA, Tamargo JL, Tendera M, Torbicki A, Wijns W, Windecker S, De Backer G, Sirnes PA, Ezquerra EA, Avogaro A, Badimon L, Baranova E, Baumgartner H, Betteridge J, Ceriello A, Fagard R, Funck-Brentano C, Gulba DC, Hasdai D, Hoes AW, Kjekshus JK, Knuuti J, Kolh P, Lev E, Mueller C, Neyses L, Nilsson PM, Perk J, Ponikowski P, Reiner Z, Sattar N, Schachinger V, Scheen A, Schirmer H, Stromberg A, Sudzhaeva S, Tamargo JL, Viigimaa M, Vlachopoulos C and Xuereb RG: ESC Guidelines on diabetes, pre-diabetes, and cardiovascular diseases developed in collaboration with the EASD: the Task Force on diabetes, pre-diabetes, and cardiovascular diseases of the European Society of Cardiology (ESC) and developed in collaboration with the European Association for the Study of Diabetes (EASD). European heart journal, 2013; 34: 3035-3087

6) Yancy CW, Jessup M, Bozkurt B, Butler J, Casey DE, Jr., Drazner MH, Fonarow GC, Geraci SA, Horwich T, Januzzi JL, Johnson MR, Kasper EK, Levy WC, Masoudi FA, McBride PE, McMurray JJ, Mitchell JE, Peterson PN, Riegel B, Sam F, Stevenson LW, Tang WH, Tsai EJ and Wilkoff BL: 2013 ACCF/AHA guideline for the management of heart failure: a report of the American College of Cardiology Foundation/American Heart Association Task Force on Practice Guidelines. Journal of the American College of Cardiology, 2013; 62: e147-239

7) Paulus WJ and Tschope C: A novel paradigm for heart failure with preserved ejection fraction: comorbidities drive myocardial dysfunction and remodeling through coronary microvascular endothelial inflammation. Journal of the American College of Cardiology, 2013; 62: 263271

8) Ho JE, Lyass A, Lee DS, Vasan RS, Kannel WB, Larson MG and Levy D: Predictors of new-onset heart failure: differences in preserved versus reduced ejection fraction. Circ Heart Fail, 2013; 6: 279-286

9) Loganathan R, Bilgen M, Al-Hafez B and Smirnova IV: Characterization of alterations in diabetic myocardial tissue using high resolution MRI. The international journal of cardiovascular imaging, 2006; 22: 81-90

10) Kwon DH, Smedira NG, Rodriguez ER, Tan C, Setser R, Thamilarasan M, Lytle BW, Lever HM and Desai MY: Cardiac magnetic resonance detection of myocardial scarring in hypertrophic cardiomyopathy: correlation with histopathology and prevalence of ventricular tachycardia. Journal of the American College of Cardiology, 2009; 54: 242-249

11) Stratton IM, Adler AI, Neil HA, Matthews DR, Manley SE, Cull CA, Hadden D, Turner RC and Holman RR: Association of glycaemia with macrovascular and microvascular complications of type 2 diabetes (UKPDS 35): prospective observational study. BMJ, 2000; 321: 405-
412

12) Higashimoto $Y$, Matsui $T$, Nishino $Y$, Taira J, Inoue $H$, Takeuchi M and Yamagishi SI: Blockade by phosphorothioate aptamers of advanced glycation end productsinduced damage in cultured pericytes and endothelial cells. Microvascular research, 2013;

13) Cheung N and Wong TY: Diabetic retinopathy and systemic vascular complications. Progress in retinal and eye research, 2008; 27: 161-176

14) Cheung N, Wang JJ, Rogers SL, Brancati F, Klein R, Sharrett AR and Wong TY: Diabetic retinopathy and risk of heart failure. Journal of the American College of Cardiology, 2008; 51: 1573-1578

15) Kurioka S, Ose H, Fukuma K and Yoshimoto K: Severity of diabetic retinopathy is associated with left ventricular diastolic dysfunction in patients with type 2 diabetes. Diabetes research and clinical practice, 2013; 99: 287-291

16) Takeda Y, Sakata Y, Mano T, Ohtani T, Tamaki S, Omori Y, Tsukamoto Y, Aizawa Y, Komuro I and Yamamoto K: Diabetic retinopathy is associated with impaired left ventricular relaxation. Journal of cardiac failure, 2011; 17: 556-560

17) Kawata T, Daimon M, Miyazaki S, Ichikawa R, Maruyama M, Chiang SJ, Ito C, Sato F, Watada H and Daida H: Coronary microvascular function is independently associated with left ventricular filling pressure in patients with type 2 diabetes mellitus. Cardiovascular diabetology, 2015; 14: 98

18) Fukami K, Yamagishi SI and Okuda S: Role of AGEsRAGE system in cardiovascular disease. Current pharmaceutical design, 2013;

19) Tahara N, Yamagishi S, Takeuchi M, Tahara A, Kaifu K, Ueda S, Okuda $S$ and Imaizumi T: Serum levels of advanced glycation end products (AGEs) are independently correlated with circulating levels of dipeptidyl peptidase-4 (DPP-4) in humans. Clinical biochemistry, 2013; 46: 300-303

20) Hatano R, Ohnuma K, Yamamoto J, Dang NH and Morimoto C: CD26-mediated co-stimulation in human CD8(+) T cells provokes effector function via pro-inflammatory cytokine production. Immunology, 2013; 138: 165-172

21) Zhong J, Rao $X$ and Rajagopalan S: An emerging role of dipeptidyl peptidase 4 (DPP4) beyond glucose control: potential implications in cardiovascular disease. Atherosclerosis, 2013; 226: 305-314

22) Murohara T: Dipeptidyl peptidase- 4 inhibitor: another player for cardiovascular protection. Journal of the American College of Cardiology, 2012; 59: 277-279

23) Matheeussen V, Jungraithmayr W and De Meester I: Dipeptidyl peptidase 4 as a therapeutic target in ischemia/ reperfusion injury. Pharmacology \& therapeutics, 2012; 136: $267-282$

24) Shigeta T, Aoyama M, Bando YK, Monji A, Mitsui T, Takatsu M, Cheng XW, Okumura T, Hirashiki A, Nagata $\mathrm{K}$ and Murohara T: Dipeptidyl peptidase-4 modulates left ventricular dysfunction in chronic heart failure via angiogenesis-dependent and -independent actions. Circulation, 2012; 126: 1838-1851

25) Lee SA, Kim YR, Yang EJ, Kwon EJ, Kim SH, Kang SH, 
Park DB, Oh BC, Kim J, Heo ST, Koh G and Lee DH: CD26/DPP4 levels in peripheral blood and $T$ cells in patients with type 2 diabetes mellitus. The Journal of clinical endocrinology and metabolism, 2013; 98: 25532561

26) Matsubara J, Sugiyama S, Akiyama E, Iwashita S, Kurokawa H, Ohba K, Maeda H, Fujisue K, Yamamoto E, Kaikita K, Hokimoto S, Jinnouchi $\mathrm{H}$ and Ogawa $\mathrm{H}$ : Dipeptidyl peptidase-4 inhibitor, sitagliptin, improves endothelial dysfunction in association with its antiinflammatory effects in patients with coronary artery disease and uncontrolled diabetes. Circ J, 2013; 77: 13371344

27) Makdissi A, Ghanim H, Vora M, Green K, Abuaysheh S, Chaudhuri A, Dhindsa S and Dandona P: Sitagliptin exerts an antinflammatory action. The Journal of clinical endocrinology and metabolism, 2012; 97: 3333-3341

28) Boudina $S$ and Abel ED: Diabetic cardiomyopathy revisited. Circulation, 2007; 115: 3213-3223

29) Poornima IG, Parikh P and Shannon RP: Diabetic cardiomyopathy: the search for a unifying hypothesis. Circulation research, 2006; 98: 596-605

30) Hu P, Zhang D, Swenson L, Chakrabarti G, Abel ED and Litwin SE: Minimally invasive aortic banding in mice: effects of altered cardiomyocyte insulin signaling during pressure overload. American journal of physiology Heart and circulatory physiology, 2003; 285: H1261-1269

31) Doenst T, Nguyen TD and Abel ED: Cardiac metabolism in heart failure: implications beyond ATP production. Circulation research, 2013; 113: 709-724

32) Parra V, Verdejo HE, Iglewski M, Campo AD, Troncoso R, Jones D, Zhu Y, Kuzmicic J, Pennanen C, LopezCrisosto C, Jana F, Ferreira J, Noguera E, Chiong M, Bernlohr DA, Klip A, Hill JA, Rothermel BA, Abel ED, Zorzano $A$ and Lavandero $S$ : Insulin stimulates mitochondrial fusion and function in cardiomyocytes via the AktmTOR-NFkappaB-Opa-1 signaling pathway. Diabetes, 2013;

33) Abel ED, O'Shea KM and Ramasamy R: Insulin resistance: metabolic mechanisms and consequences in the heart. Arteriosclerosis, thrombosis, and vascular biology, 2012; 32: 2068-2076

34) Shimizu I, Minamino T, Toko H, Okada S, Ikeda H, Yasuda N, Tateno K, Moriya J, Yokoyama M, Nojima A, Koh GY, Akazawa H, Shiojima I, Kahn CR, Abel ED and Komuro I: Excessive cardiac insulin signaling exacerbates systolic dysfunction induced by pressure overload in rodents. The Journal of clinical investigation, 2010; 120: 1506-1514

35) Monji A, Mitsui T, Bando YK, Aoyama M, Shigeta T and Murohara T: Glucagon-like peptide-1 receptor activation reverses cardiac remodeling via normalizing cardiac steatosis and oxidative stress in type 2 diabetes. American journal of physiology Heart and circulatory physiology, 2013; 305: H295-304

36) Ramirez E, Klett-Mingo M, Ares-Carrasco S, Picatoste B, Ferrarini A, Ruperez FJ, Caro-Vadillo A, Barbas C, Egido J, Tunon J and Lorenzo O: Eplerenone attenuated cardiac steatosis, apoptosis and diastolic dysfunction in experimental type-II diabetes. Cardiovascular diabetology, 2013;
12: 172

37) Noyan-Ashraf MH, Shikatani EA, Schuiki I, Mukovozov I, Wu J, Li RK, Volchuk A, Robinson LA, Billia F, Drucker DJ and Husain M: A glucagon-like peptide-1 analog reverses the molecular pathology and cardiac dysfunction of a mouse model of obesity. Circulation, 2013; 127: 74-85

38) McGavock JM, Lingvay I, Zib I, Tillery T, Salas N, Unger R, Levine BD, Raskin P, Victor RG and Szczepaniak LS: Cardiac steatosis in diabetes mellitus: a $1 \mathrm{H}$-magnetic resonance spectroscopy study. Circulation, 2007; 116: 11701175

39) Rijzewijk LJ, van der Meer RW, Smit JW, Diamant M, Bax JJ, Hammer S, Romijn JA, de Roos A and Lamb HJ: Myocardial steatosis is an independent predictor of diastolic dysfunction in type 2 diabetes mellitus. Journal of the American College of Cardiology, 2008; 52: 17931799

40) Lan HY: Transforming growth factor-beta/Smad signalling in diabetic nephropathy. Clinical and experimental pharmacology \& physiology, 2012; 39: 731-738

41) Asbun J and Villarreal FJ: The pathogenesis of myocardial fibrosis in the setting of diabetic cardiomyopathy. Journal of the American College of Cardiology, 2006; 47: 693700

42) Zieman S and Kass D: Advanced glycation end product cross-linking: pathophysiologic role and therapeutic target in cardiovascular disease. Congest Heart Fail, 2004; 10: 144-149; quiz 150-141

43) Cieslik KA, Trial J, Carlson S, Taffet GE and Entman ML: Aberrant differentiation of fibroblast progenitors contributes to fibrosis in the aged murine heart: role of elevated circulating insulin levels. FASEB journal : official publication of the Federation of American Societies for Experimental Biology, 2013; 27: 1761-1771

44) Van Linthout S, Seeland U, Riad A, Eckhardt O, Hohl M, Dhayat N, Richter U, Fischer JW, Bohm M, Pauschinger M, Schultheiss HP and Tschope C: Reduced MMP-2 activity contributes to cardiac fibrosis in experimental diabetic cardiomyopathy. Basic research in cardiology, 2008; 103: 319-327

45) Kaji K, Yoshiji H, Ikenaka Y, Noguchi R, Aihara Y, Douhara A, Moriya K, Kawaratani H, Shirai Y, Yoshii J, Yanase K, Kitade M, Namisaki T and Fukui H: Dipeptidyl peptidase- 4 inhibitor attenuates hepatic fibrosis via suppression of activated hepatic stellate cell in rats. Journal of gastroenterology, 2014; 49: 481-491

46) Panchapakesan U and Pollock C: The Role of Dipeptidyl Peptidase - 4 Inhibitors in Diabetic Kidney Disease. Frontiers in immunology, 2015; 6: 443

47) Keane FM, Nadvi NA, Yao TW and Gorrell MD: Neuropeptide $\mathrm{Y}, \mathrm{B}$-type natriuretic peptide, substance $\mathrm{P}$ and peptide YY are novel substrates of fibroblast activation protein-alpha. The FEBS journal, 2011; 278: 1316-1332

48) Davi G, Catalano I, Averna M, Notarbartolo A, Strano A, Ciabattoni $\mathrm{G}$ and Patrono C: Thromboxane biosynthesis and platelet function in type II diabetes mellitus. The New England journal of medicine, 1990; 322: 1769-1774

49) Spectre G, Ostenson CG, Li N and Hjemdahl P: Postprandial platelet activation is related to postprandial 
plasma insulin rather than glucose in patients with type 2 diabetes. Diabetes, 2012; 61: 2380-2384

50) Santilli F, Formoso G, Sbraccia P, Averna M, Miccoli R, Di Fulvio P, Ganci A, Pulizzi N, Lattanzio S, Ciabattoni G, Consoli A, Lauro R, Patrono C and Davi G: Postprandial hyperglycemia is a determinant of platelet activation in early type 2 diabetes mellitus. Journal of thrombosis and haemostasis : JTH, 2010; 8: 828-837

51) Granger DN, Rodrigues SF, Yildirim A and Senchenkova EY: Microvascular responses to cardiovascular risk factors. Microcirculation, 2010; 17: 192-205

52) Brooks BA, Franjic B, Ban CR, Swaraj K, Yue DK, Celermajer DS and Twigg SM: Diastolic dysfunction and abnormalities of the microcirculation in type 2 diabetes. Diabetes, obesity \& metabolism, 2008; 10: 739-746

53) Herrmann J, Kaski JC and Lerman A: Coronary microvascular dysfunction in the clinical setting: from mystery to reality. European heart journal, 2012; 33: 2771-2782b

54) Ogawa H, Nakayama M, Morimoto T, Uemura S, Kanauchi M, Doi N, Jinnouchi H, Sugiyama $S$ and Saito Y: Low-dose aspirin for primary prevention of atherosclerotic events in patients with type 2 diabetes: a randomized controlled trial. JAMA : the journal of the American Medical Association, 2008; 300: 2134-2141

55) Cerbone AM, Macarone-Palmieri N, Saldalamacchia G, Coppola A, Di Minno G and Rivellese AA: Diabetes, vascular complications and antiplatelet therapy: open problems. Acta diabetologica, 2009; 46: 253-261

56) Krijnen PA, Hahn NE, Kholova I, Baylan U, Sipkens JA, van Alphen FP, Vonk AB, Simsek S, Meischl C, Schalkwijk CG, van Buul JD, van Hinsbergh VW and Niessen HW: Loss of DPP4 activity is related to a prothrombogenic status of endothelial cells: implications for the coronary microvasculature of myocardial infarction patients. Basic research in cardiology, 2012; 107: 233

57) Borlaug BA and Paulus WJ: Heart failure with preserved ejection fraction: pathophysiology, diagnosis, and treatment. European heart journal, 2011; 32: 670-679

58) Lane DJ, Huang ML, Ting S, Sivagurunathan $S$ and Richardson DR: Biochemistry of cardiomyopathy in the mitochondrial disease Friedreich's ataxia. The Biochemical journal, 2013; 453: 321-336

59) Faden G, Faganello G, De Feo S, Berlinghieri N, Tarantini L, Di Lenarda A, Faggiano P and Cioffi G: The increasing detection of asymptomatic left ventricular dysfunction in patients with type 2 diabetes mellitus without overt cardiac disease: data from the SHORTWAVE study. Diabetes research and clinical practice, 2013; 101: 309316

60) Ernande L, Rietzschel ER, Bergerot C, De Buyzere ML, Schnell F, Groisne L, Ovize M, Croisille P, Moulin P, Gillebert TC and Derumeaux G: Impaired myocardial radial function in asymptomatic patients with type 2 diabetes mellitus: a speckle-tracking imaging study. Journal of the American Society of Echocardiography : official publication of the American Society of Echocardiography, 2010; 23: $1266-1272$

61) Miki T, Yuda S, Kouzu H and Miura T: Diabetic cardiomyopathy: pathophysiology and clinical features. Heart failure reviews, 2013; 18: 149-166

62) Mentlein R: Cell-surface peptidases. Int Rev Cytol, 2004; 235: $165-213$

63) Bando YK and Murohara T: Diabetes-related heart failure. Circ J, 2014; 78: 576-583

64) Scheen AJ: Cardiovascular effects of dipeptidyl peptidase- 4 inhibitors: from risk factors to clinical outcomes. Postgrad Med, 2013; 125: 7-20

65) Zannad F, Cannon CP, Cushman WC, Bakris GL, Menon V, Perez AT, Fleck PR, Mehta CR, Kupfer S, Wilson C, Lam H, White WB and Investigators E: Heart failure and mortality outcomes in patients with type 2 diabetes taking alogliptin versus placebo in EXAMINE: a multicentre, randomised, double-blind trial. Lancet, 2015; 385: 2067-2076

66) Goldfine AB: Assessing the cardiovascular safety of diabetes therapies. The New England journal of medicine, 2008; 359: 1092-1095

67) Scirica BM, Bhatt DL, Braunwald E, Steg PG, Davidson J, Hirshberg B, Ohman P, Frederich R, Wiviott SD, Hoffman EB, Cavender MA, Udell JA, Desai NR, Mosenzon O, McGuire DK, Ray KK, Leiter LA, Raz I, Committee S-TS and Investigators: Saxagliptin and cardiovascular outcomes in patients with type 2 diabetes mellitus. The New England journal of medicine, 2013; 369: 1317-1326

68) White WB, Cannon CP, Heller SR, Nissen SE, Bergenstal RM, Bakris GL, Perez AT, Fleck PR, Mehta CR, Kupfer S, Wilson C, Cushman WC, Zannad F and Investigators E: Alogliptin after acute coronary syndrome in patients with type 2 diabetes. The New England journal of medicine, 2013; 369: 1327-1335

69) Scirica BM, Braunwald E, Raz I, Cavender MA, Morrow DA, Jarolim P, Udell JA, Mosenzon O, Im K, Umez-Eronini AA, Pollack PS, Hirshberg B, Frederich R, Lewis BS, McGuire DK, Davidson J, Steg PG, Bhatt DL, Committee S-TS and Investigators*: Heart failure, saxagliptin, and diabetes mellitus: observations from the SAVOR-TIMI 53 randomized trial. Circulation, 2014; 130: 1579-1588

70) Green JB, Bethel MA, Armstrong PW, Buse JB, Engel SS, Garg J, Josse R, Kaufman KD, Koglin J, Korn S, Lachin JM, McGuire DK, Pencina MJ, Standl E, Stein PP, Suryawanshi S, Van de Werf F, Peterson ED, Holman RR and Group TS: Effect of Sitagliptin on Cardiovascular Outcomes in Type 2 Diabetes. The New England journal of medicine, 2015; 373: 232-242 